\title{
Effect of dietary Ergosan and Hilyses on growth performance, hema- tological variables and immune response in rainbow trout (Oncorhyn- chus mykiss)
}

\author{
M Akbari ${ }^{1,2}$, M Heidarieh ${ }^{1}$, A Mirvaghefi ${ }^{2}$, H Farahmand ${ }^{2}$, N Sheikhzadeh ${ }^{3}$ and E Najafi Hajivar ${ }^{1}$ \\ ${ }^{1}$ Agricultural, Medical and Industrial Research School (AMIRS-NSTRI), Karaj, Iran \\ ${ }^{2}$ Department of Fisheries and Environment Science, Faculty of Natural Resources, University of Tehran, Tehran, \\ Iran \\ ${ }^{3}$ Department of Food Hygiene and Aquatic Animals, Faculty of Veterinary Medicine, University of Tabriz, Ta- \\ briz, Iran
}

Received: April 2014

\section{Abstract}

This study was conducted to evaluate the efficiency of Ergosan, an algal extract containing alginic acid and Hilyses, a fermented Saccharomyces cerevisi$a e$, on growth, immune response and hematological parameters in rainbow trout (Oncorhynchus mykiss). Fish with an initial average weight of 70-75 g were fed with Ergosan $\left(5 \mathrm{~g} \mathrm{~kg}^{-1}\right)$ and Hilyses $(10 \mathrm{~g}$ $\mathrm{kg}^{-1}$ ) for a period of 70 days. The Results revealed that dietary supplementation of Ergosan and Hilyses enhanced the growth of all treated fish significantly compared to fish fed with non-supplemented diet. Dietary intake of Ergosan significantly increased the red blood cell, white blood cell and neutrophil levels compared to the Hilyses-fed and control groups. The highest IL-8 level and lysozyme activity were recorded in the Hilyses-fed fish followed by Ergosan. Serum total protein content was enhanced in fishes administrated with Ergosan compared to the control group. The findings of this study suggested the potential of Ergosan and Hilyses to activate growth performance and immunological parameters in rainbow trout.

Keywords: rainbow trout, Ergosan, Hilyses, growth, immune response.

Correspondence M Heidarieh, Agricultural Medical and Industrial Research School (AMIRS-NSTRI), Karaj, Iran, (e-mail: mheidarieh@nrcam.org,)
Accepted: July 2014

\section{Introduction}

Nowadays, intensive culture of fish species with exposure to various stress factors such as handling, crowding and infection has led to immune depression and outbreaks of infections (El-Boshy, El-Ashram, AbdelHamid \& Gadalla 2010). Immunostimulants comprise a group of biological and synthetic compounds that increase the nonspecific cellular and humoral defence mechanisms in fish species. These substances, such as $\beta$-glucan, peptidoglycan, chitin, chitosan yeast and vitamin combinations, as well as various products derived from plants and animals are effective in preventing disease (Gopalakannan \& Arul 2006).

Baker's yeast (Saccharomyces cerevisiae) is a natural product used for the bakers' industry which contains various immunostimulating compounds such as $\beta$-glucan, nucleic acids, mannan oligosaccharides and chitin (Tukmechi, Andarani, Manaffar \& Sheikhzadeh 2011). Hilyses yeast, an additive obtained from fermentation of specific strains of $S$. cerevisiae consists of nucleotides, glutamine, glutamate, free amino acid and peptide. Effects of $S$. cerevisiae fermentation product on fish growth and immunity were previously reported (Barnes, Durben, Reeves \& Sandes 2006; He, Zhou, Liu, Shi, Yao, Ringø \& Yoon 2009).

Alginic acid is derived from several genera of brown algae including Macrocystis, Laminaria, Lessonia, Ascophyllum, Alaria, Ecklonia, Eisenia, Neroe- 
cystis, Sargassum, Cystoseira and Fucus (Peddie, Zou \& Secombes 2002). Ergosan is an algal extract composed of $0.002 \%$ unspecified plant extract, $1 \%$ alginic acid from Laminaria digitata, and 98.998\% algal based carrier. Algines have been used for a range of commercial applications including thickening agents, gelling agents and dispersion stabilizers (Peddie et al., 2002). There are some studies in the literature revealing the effects of Ergosan on fish growth, immunity and hematological parameters (Peddie et al,. 2002; Montero-Rocha, McIntosh, Sanchez-Merino \& Flores 2006; Jalali, Ahmadifar, Sudagar \& Takami 2009; Gioacchini, Lombardo, Avella, Olivotto \& Carnevali 2010). Therefore, this study aimed to evaluate and compare the efficiency of two immunostimulants, Ergosan and Hilyses, after 70 days administration on some haematological and immunological parameters as well as growth performance of rainbow trout (Oncorhynchus mykiss).

\section{Materials and Methods}

\section{Fish and Experimental design}

A total number of 99 rainbow trout weighing 70$75 \mathrm{~g}$ were obtained from a fish farm in Karaj, and maintained in tanks with continuously aerated free-flowing dechlorinated fresh water at $14 \pm 1{ }^{\circ} \mathrm{C}$. The fish were acclimatized to the laboratory condition for 12 days and fed with commercial pelleted diet (Faradaneh, Fish feed manufature, Iran) at a level of $3 \%$ body weight four times daily. The proximate composition of basal diet comprised 38\% crude protein, $14 \%$ crude lipid, $10 \%$ crude ash, and $4 \%$ crude fiber. Fsh were randomly distributed in three equal groups. Each group consisted of three replicates of 11 fish For a period of 70 days were fed with diet containing $5 \mathrm{~g} \mathrm{~kg}^{-1}$ of Ergosan according to manufacturer's recommendation (Schering-Plough Aquaculture, UK) and $10 \mathrm{~g} \mathrm{~kg}^{-1}$ of Hilyses (according to manufacturer's recommendation).

\section{Growth performance}

At the end of the feeding period, all fish from each individual tank were weighted, and weight gain, feed conversion ratio (FCR) and specific growth rate (SGR) were calculated as follows:

Weight gain = final weight $(\mathrm{g})$ - initial weight $(\mathrm{g})$

$\mathrm{FCR}=$ feed given $(\mathrm{g}) /$ weight gain $(\mathrm{g})$

$\mathrm{SGR}=\left(\left(\ln \mathrm{W}_{2}-\ln \mathrm{W} 1\right) / \mathrm{T}\right) 100$

Where $\mathrm{W}_{1}, \mathrm{~W}_{2}$, and $\mathrm{T}$ are the initial weight, final weight, and number of days in the feeding trial, respectively.

\section{Blood collection}

After 70 days of the feeding period, 10 fish in each tank were anaesthetized with clove oil bath $(50 \mu 1$ $1^{-1}$ ), then bled from the caudal peduncle by heparin syringes. The blood was then divided into two aliquots. One was heparinized, and the other was permitted to clot for $30 \mathrm{~min}$ at room temperature and then maintained for $5 \mathrm{~h}$ at $4^{\circ} \mathrm{C}$. The clotted samples were centrifuged for $15 \mathrm{~min}$ at $3000 \mathrm{RPM}$ at $4^{\circ} \mathrm{C}$ in order to collect the serum. The heparinized blood was immediately utilized for the haematological assays.

\section{Haematological parameters}

Red blood cells (RBCs) and white blood cells (WBCs) were counted using a Neubauer haemocytomter after dilution with phosphate-buffered-saline (PBS). Differential leukocyte counts namely neutrophil and lymphocyte were determined using blood smears under a light microscope. Hematocrit values (Hct) were determined by placing fresh blood in glass capillary tubes and centrifuging for 5 $\min$ in a microhematocrit centrifuge.

Level of interleukin-8 (IL-8) in fish serum was quantified using an IL-8 ELISA kit (Koma Biotech, Seoul, Korea) according to the manufacturer's instructions. Briefly, a rabbit anti-Human IL-8 pre-coated 96-well plate was incubated with 100 $\mu \mathrm{L}$ of standard or sample to each well in duplicate. After incubation for $2 \mathrm{~h}$ at room temperature, the plates were washed four times with PBS, $0.01 \%$ $(\mathrm{v} / \mathrm{v})$ Tween 20. After washing, biotinylated purified anti-Human IL-8 antibody ( $\left.5 \mu \mathrm{g} \mathrm{mL}^{-1}\right)$ was added and incubated for $2 \mathrm{~h}$. The plates were washed four times and incubated with $100 \mu \mathrm{l}$ of the streptavidin-HRP conjugate (1:20 dilutions) for $30 \mathrm{~min}$. After final incubation with $100 \mu 1$ of color devel- 
opment reagent (pink-ONE TMB solution) for 15 min, the reaction was stopped by adding $100 \mu \mathrm{L}$ of the $2 \mathrm{M}$ sulphuric acid to the wells. The plates were read at $450 \mathrm{~nm}$ using a microtiter plate reader. OD readings were converted to $\mathrm{pg} \mathrm{mL}^{-1}$ using a standard curve and the appropriate dilution factor.

\section{Lysozyme assay}

Serum lysozyme activity was estimated by turbidimetric assay as described by Demers \& Bayne (1997). Micrococcus lysodeikticus (M. lysodeikticus) (Sigma) suspended in 0.1 M phosphate citrate buffer, $\mathrm{pH} 5.8$ at a concentration of $750 \mu \mathrm{g} \mathrm{mL}^{-1} \mathrm{was}$ added to $25 \mu \mathrm{L}$ of serum samples in 96-well microtiter plates. Immediately after the addition of 150 $\mu \mathrm{L}$ of M. lysodeikticus, the optical density was determined. A lysozyme activity unit was calculated as the amount of enzyme producing a decrease in absorbance of $0.001 \mathrm{~min}^{-1}$.

\section{Serum protein level}

The protein concentration was determined according to biuret method using a commercial kit (Ziestchem diagnostics Co. Ltd., Tehran, Iran) in accordance with the manufacturer's protocols.

\section{Statistical analysis}

All data were presented as means \pm SEM of three replicates treatments. Statistical analysis of data was carried out using one-way ANOVA and Tukey multiple range tests using SPSS for windows software, version 17. Differences in treatment means were considered significant at $\mathrm{P}<0.05$.

\section{Results}

The growth parameters of weight gain, FCR and SGR in fish fed with Ergosan and Hilyses increased compared to the control fish group. No significant difference in growth performance between treatment groups was noted (Table 1).

Higher RBC, WBC and neutrophil counts were found in fish fed Ergosan than in fish fed Hilyses and control diet. No significant differences in Hct and lymphocyte values were shown in different groups (Table 2).
Table 1 Growth performance of rainbow trout fed with immunostimulant supplemented diet for 70 days

\begin{tabular}{llll}
\hline Treatments & \multicolumn{2}{l}{ Growth parameters } \\
\cline { 2 - 4 } & Weight gain & $\begin{array}{l}\text { Feed conver- } \\
\text { sion ratio }\end{array}$ & $\begin{array}{l}\text { Specific growth } \\
\text { rate }\end{array}$ \\
\hline Control & $74.32 \pm 8.32^{\mathrm{a}}$ & $1.83 \pm 0.18^{\mathrm{a}}$ & $3.24 \pm 0.78^{\mathrm{a}}$ \\
Ergosan & $119.28 \pm 4.03^{\mathrm{b}}$ & $1.19 \pm 0.33^{\mathrm{b}}$ & $4.42 \pm 0.31^{\mathrm{b}}$ \\
Hilyses & $113.03 \pm 7.11^{\mathrm{b}}$ & $1.21 \pm 0.09^{\mathrm{b}}$ & $4.38 \pm 0.18^{\mathrm{b}}$ \\
\hline
\end{tabular}

Means with the same letter in the same column are not significantly different $(\mathrm{P}<0.05)$.

Higher IL-8 was found in fish fed Hilyses (228.22 $\pm 23.88)$ and Ergosan $(142.11 \pm 0.4)$ than was observed in the control group. Higher lysozyme activity was shown in the Hilyses group $(5.33 \pm 1.38)$ followed by Ergosan group compared with the control group. The protein level of fish that received Ergosan increased compared with control group but no significant differences were found between treatment groups (Table 3).

\section{Discussion}

Fish feed supplementation with Ergosan and Hilyses was clearly beneficial, as indicated by the increased growth performance. In this study, all treatment groups showed higher gains in the body weight and SGR than the control group after a period of 70 days feeding. These findings are in accordance with the those on rainbow trout that received fermented S. cerevisiae (Barnes et al. 2006) and Ergosan (Gioacchini et al. 2010). Although the exact mechanism of improved growth in treatment groups is not clear, a number of factors such as better digestibility, immunomodulatory effects, positive effects on digestive enzyme activities, a reduction in pathogenic bacteria and an increase in positive bacteria in the fish gut have been proposed (Heidarieh et al. 2012). Hematological parameters of fish blood are useful tools that aid in diagnosis of disease. It can also be used to study immnuopotentiators. Haematological parameters showed significant changes in Ergosan-treated group in comparison with Hilyses-treated and control groups. In this study, elevated levels of RBC, WBC and neutrophil were observed in fish that received Ergosan. Similarly a higher number of lymphocytes were observed in the 
M Akbari et al., Effect of immunostimulators on growth and immunophysiology of trout

Table 2 Hematological changes of rainbow trout fed with immunostimulant supplemented diet for 70 days

\begin{tabular}{llllll}
\hline Treatments & \multicolumn{5}{l}{ Hematological parameters } \\
\cline { 2 - 6 } & RBC & WBC & Hct & Lymphocyte & Neutrophil \\
\hline \multirow{2}{*}{ Control } & $\left(\times 10^{6} \mathrm{~mm}^{3}\right)$ & $\left(\times 10^{4} \mathrm{~mm}^{3}\right)$ & $(\%)$ & $(\%$ of WBC $)$ & $(\%$ of WBC $)$ \\
Ergosan & $9.44 \pm 0.68^{\mathrm{a}}$ & $59.80 \pm 4.97^{\mathrm{a}}$ & $40.25 \pm 1.45^{\mathrm{a}}$ & $92.66 \pm 3.20^{\mathrm{a}}$ & $7.33 \pm 3.21^{\mathrm{a}}$ \\
Hilyses & $12.18 \pm 0.33^{\mathrm{b}}$ & $109.0 \pm 19.82^{\mathrm{b}}$ & $39.33 \pm 2.08^{\mathrm{a}}$ & $88.70 \pm 4.35^{\mathrm{a}}$ & $11.66 \pm 3.05^{\mathrm{b}}$ \\
\hline
\end{tabular}

Means with the same letter in the same column are not significantly different $(\mathrm{P}<0.05)$.

Table 3 Immunological changes of rainbow trout fed with immunostimulant supplemented diet for 70 days

\begin{tabular}{llll}
\hline \multirow{2}{*}{ Treatments } & \multicolumn{2}{l}{ Immunological parameters } \\
\cline { 2 - 4 } & IL-8 & Lysozyme & Total protein \\
\hline \multirow{2}{*}{ Control } & $73.58 \pm 3.42^{\mathrm{a}}$ & $\left(\mathrm{U} \mathrm{mL}^{-1}\right)$ & $\left(\mathrm{g} \mathrm{dL}^{-1}\right)$ \\
Ergosan & $142.11 \pm 0.4^{\mathrm{b}}$ & $2.43 \pm 0.42^{\mathrm{a}}$ & $0.41 \pm 0.02^{\mathrm{a}}$ \\
Hilyses & $228.22 \pm 23.88^{\mathrm{c}}$ & $5.33 \pm 1.38^{\mathrm{c}}$ & $0.42 \pm 0.01^{\mathrm{b}}$ \\
\hline
\end{tabular}

Means with the same letter in the same column are not significantly different $(\mathrm{P}<0.05)$.

blood of fish that received Ergosan-supplemented diets (Jalali et al. 2009; Heidarieh, Soltani, Tamimi \& Toluei 2011). Total and differential leukocytes counts are important indices in fish as leukocytes are involved in phagocytic and immune responses to pathogens (Tukmechi et al. 2011).

Plasma proteins include the humeral elements of the nonspecific immune system such as immunoglobulin (Tukmechi et al. 2011). In our study, the serum protein level was found to increase in fish fed with Ergosan. This study also indicated that fish treatment with Hilyses and Ergosan were effective in enhancing serum lysozyme activity. Lysozymes have an important role in innate immunity by lysis of bacterial cell walls, especially gram-positive bacteria and stimulate phagocytosis of bacteria. It is believed that the main sources of serum lysozyme are leukocyte cells, particularly basophils, monocytes and the lower rate from macrophages (Saurabh \& Sahoo 2008). A significant increase in neutrophil count was just observed in an Ergosan treatment group. Such increase can cause an enhancement in lysozyme level of serum as seen in this study. However, no changes were found in neutrophil levels of fish administrated with Hilyses. Therefore, other mechanisms might be involved in elevating lysozyme activity in fish treated with Hilyses.
IL-8 is a chemokine produced by cell types of macrophages/monocytes, epithelial cells, neutrophils, fibroblasts, and endothelial cells upon infection or stimulated by cytokines such as $\mathrm{IL}^{-1}$ and TNF- $\alpha$ (Jimenez, Coll, Salguero \& Tafalla 2006). In this study, significant increase in IL-8 level was shown in fish sera administrated with Hilyses and Ergosan. Intraperitoneal injection of Ergosan (1\% alginic acid) at doses $>2.5 \mathrm{mg} \mathrm{kg}^{-1}$ augmented the expression of chemokines (IL-8) in rainbow trout leucocytes (Peddie et al. 2002). Similarly, in rainbow trout fed on alginic acid, IL- 8 gene expression in spleen was significantly higher compared with control group (Gioacchini et al. 2010). The effect of various immunostimulants is related to what pattern recognition receptors they bind to and the immune responses of these receptors effect (Bricknell \& Dalmo 2005). In this study, it seems that alginic acid and products from fermented S. Service (Hilyses) are legends for different receptors, and may be expected to cause different immune responses in fish (Iwamoto, Kurachi, Nakashima, Kim, Yamaguchi, Oda, Iwamoto \& Muramatsu 2005).

In conclusion, these results show that Ergosan (5 $\left.\mathrm{g} \mathrm{kg}^{-1}\right)$ and Hilyses $\left(10 \mathrm{~g} \mathrm{~kg}^{-1}\right)$ are able to enhance some nonspecific immunity and growth status of rainbow trout. Therefore, use of these immunostimulators can benefit the fish farmers via increasing the growth performance and immune system of fish. Acknowledgements The authors are grateful for the financial support provided by Agricultural, Medical and Industrial Research School (AMIRS-NSTRI), Karaj, Iran, and Department of Fisheries and Environment Science, Faculty of Natural Resources, University of Tehran. 


\section{References}

Barnes M.E., Durben D.J., Reeves SG. \& Sandes R. (2006) Dietary yeast culture supplementation improves initial rearing of McConaughy strain rainbow trout. Aquaculture Nutrition 12, 388-394.

Bricknell I. \& Dalmo RA. (2005) The use of immunostimulants in fish larval aquaculture. Fish and Shellfish Immunology 19, 457-472.

Demers N.E. \& Bayne C.J. (1997) The immediate effects of stress on hormones and plasma lysozyme in rainbow trout. Development and Comparative Immunology 21, 363-373.

El-Boshy M.E., El-Ashram A.M., AbdelHamid F.M. \& Gadalla H.A. (2010) Immunomodulatory effect of dietary Saccharomyces cerevisiae, b-glucan and laminaran in mercuric chloride treated Nile tilapia (Oreochromis niloticus) and experimentally infected with Aeromonas hydrophila. Fish and Shellfish Immunology 28, 802-808.

Gioacchini G., Lombardo F., Avella M.A., Olivotto I. \& Carnevali O. (2010) Welfare improvement using alginic acid in rainbow trout (Oncorhynchus mykiss) juveniles. Chemistry and Ecology 26, 111-121.

Gopalakannan A. \& Arul V. (2006) Immunomodulatory effects of dietary intake of chitin, chitosan and levamisole on the immune system of Cyprinus carpio and control of Aeromonas hydrophila infection in ponds. Aquaculture 255, 179-187.

He S., Zhou Z., Liu Y., Shi P., Yao B., Ringø E. \& Yoon I. (2009) Effects of dietary Saccharomyces cerevisiae fermentation product (DVAQUA ${ }^{\star}$ ) on growth performance, intestinal autochthonous bacterial community and non-specific immunity of hybrid tilapia (Oreochromis niloticus $\bigcap_{\times}$O. aureus $\hat{\jmath}$ ) cultured in cages. Aquaculture 294, 99-107.

Iwamoto M., Kurachi M., Nakashima T., Kim D., Yamaguchi K., Oda T., Iwamoto Y. \& Muramatsu T. (2005) Structure-activity relationship of alginate oligosaccharides in the induction of cytokine production from RAW
264.7 cells. FEBS Letters 579, 4423-4429.

Jalali M.A., Ahmadifar E., Sudagar M. \& Takami G.A. (2009) Growth efficiency, body composition, survival and haematological changes in great sturgeon (Huso huso Linnaeus, 1758) juveniles fed diets supplemented with different levels of Ergosan. Aquaculture Research 40, 804-809.

Jimenez N., Coll J., Salguero F.J. \& Tafalla C. (2006) Co-injection of interleukin 8 with the glycoprotein gene from viral haemorrhagic septicemia virus (VHSV) modulates the cytokine response in rainbow trout (Oncorhynchus mykiss). Vaccine 24, 5615-5626.

Montero-Rocha A., McIntosh D., Sanchez-Merino R. \& Flores I. (2006) Immunostimulation of white shrimp ( $L i-$ topenaeus vannamei) following dietary administration of Ergosan. Journal of Invertebrate Pathology 91, 188-194.

Peddie S., Zou J. \& Secombes C.J. (2002) Immunostimulation in the rainbow trout (Oncorhynchus mykiss) following intraperitoneal administration of Ergosan. Veterinary Immunology and Immunopathology 86, 101-113.

Saurabh S. \& Sahoo P.K. (2008) Lysozyme: an important defence molecule of fish innate immune system. Aquaculture Research 39, 223-239.

Tukmechi A., Rahmati Andarani H.R., Manaffar R. \& Sheikhzadeh N. (2011) Dietary administration of beta-mercapto-ethanol treated Saccharomyces cerevisiae enhanced the growth, innate immune response and disease resistance of the rainbow trout (Oncorhynchus mykiss). Fish and Shellish Immunology 30, 923-928. 


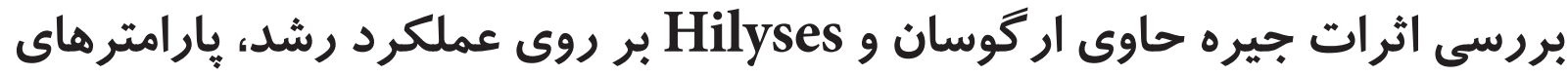 خونى و ياسخ ايمنى در ماهى قزل آلآى رنكين كمان (Oncorhynchus mykiss)}

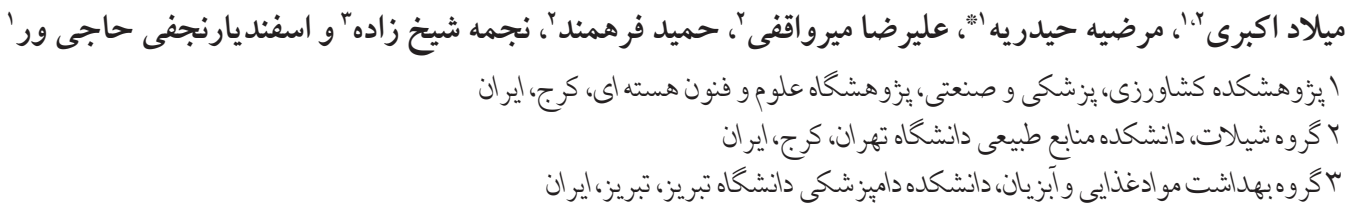

در اين مطالعه اثرات جيره حاوى ارگّوسان و عصاره جلبك حاوى اسيد آلزينيك و Hilyses بر روى رشد، سيسته ايمنى و يارامترهاى خونى ماهى

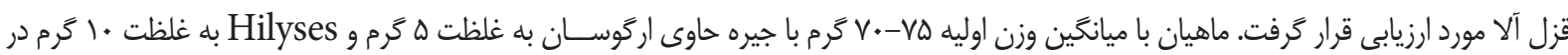

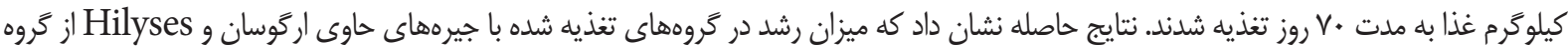

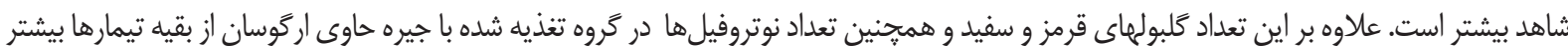

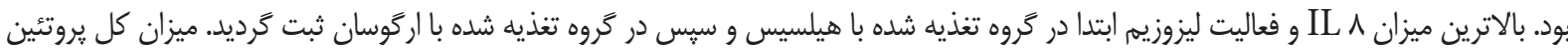

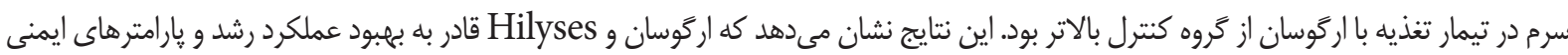
در ماهيان قزل آلا هستند. وازههاى كليدى: قزل الاى رنخين كمان، اركوسان، Hilyses، يارامترهاى خونى، پِاسخ ايمنى. * mheidarieh@nrcam.org : 